\section{1. 安全人間工学部会の活動再開}

（旧）安全人間工学部会は、昭和 56 年 3 月に、「人 的事故の原因分析手順書」を部会の研究成果としてまと め、その活動を整了した。活勤整了の主要な理由は *内規による研究部会の活堛期間に従ったこと *具体的な安全対策についての踰譜は、個別の ケースを対象に行なう必要があり、これが部 会の活動限界を越えると判断されたこと にあるが、人間工学の立埸からの安全問題への取組み、 すなわち安全人間工学は、総論の籁囲をこえて具体的な 対策を提言できるところにまで踏込まないと、実践科学 または応用技術学としての人間工学の使命を果したこと にはならないところに、この部会の困難さがある。

しかし、あえてこの困難なを越えるため、昭和 58 年 度から安全人間工学部会を発足させ、「自動化システム 分科会」と繁急時安全分科会」の二つの分科会によって 活動を開始した。

第1回の両部会連合研究会では、埼玉工業大学・井上 教授が [安全人間工学への期待と提言]の中で、

1 ) 自動化（ロボット化）の進むべき道と安全 对策

2 ) 中高年者と安全

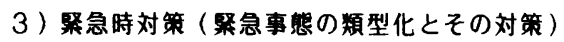

4) 誤操作の科学的分析

などを强拥した。部会では、こうした安全工学の研究者 の期待と提言を謙虚に受けとめ、部会活動の中に反映さ せる必要がある。

\section{2. 自動化システム分科会の進め方}

生産システム自動化がいかに高度のものになろうとも、 随所に人間と機械の接点が構成されているのが現実の生 産現場の努である。こうした生産システムの安全は、

設計建設運転保守管理

のすべての部門で関わりがあるが、自郋化システム分科 会では運転・保守・管理に焦点を校り、これを研究活動 の对象にすることにした。

安全人間工学の理念は、ということがよく論僮の对象 になるが、[All Accidents are Preventable] ]前提 に、事故の危険性からいかに遠のくかを目標に進むのが、 この分科会の使命ではないかと考える。

自動化システムに関わるHuman Factors は、

1 ) 設備・計等の人間工学的諸問題

2 ) 従事員に対して要求する瀻務・能カレベル

3) 徒事員のWork Load の問題

\section{4 ) 人間の信頼性の問題}

5 ) 徒事員の教育・訓練の問題

など、きわめて多岐にわたることはいうまでもなく、こ れが、安全の人間的側面を複雓なものとし、ひいては、 安全人間工学の進むべき道に原い壁となって、実践的な 研究の障害になっているのはまぎれもない事実である。

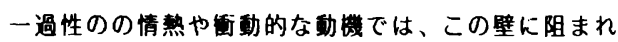

て前進を断念せざるをえないことになろう。

分科会の活動を始めるに際しては、予めこれらの障害 を越えなければ安全人間工学の飛羅のないことを決意し

て、着実に進むことにした。

3.第1回例会で取りあげたテーマとその内容

第 1 回の例会は昭和 59 年 4 月 24 日に開催されたが、 この例会の主題は [自動化システムにおけるwork load をめぐって〕である。

第1回の例会でwork load を取りあげた理由は、自動 化の程度が進むほど生産システムでの徒事貝の作業は監 視的業務が主体となり、フコセスの進行に直接的に介入 することは少なくなるが、いったん、異常状態などの徵 候が現れたり、それが緊急事態に発展するような感念を 生じた場合には、一転して従事貝の介入が切迫した時間 のもとで要求されるという、作業要求の著しい落差に着 目したからである。

作業はあらかじめ約束された秩序にもとついて外界に 㭷きかける行動様式のひとつである。作業の遂行は、外 界の情報の受入れ（情報入力系）、新束に適合するよう な最適処理（情報変换・処理系）、動作として外界上動 きかける (出力系) などの機能分担と手順を経て行なわ れる。そして、これらの系への要求度の比重によって、 筋的作業または神経的作業と呼ぶことが多い。また、入 力系や出力系への要求度は大きくないが、変换・処理系 への要求が主体となるものを精神的あるいは心的作業と 呼ぶこともあるが、こうした分類はいすれも便宜的なも のである。

作業の遂行は、その性質や単位時間当たりの作業量に 応じた心身の活動を要求するが、具体的に作業の内容や 条件が決っている場合にはこれをwork load（作業負荷） と呼ぶのが通例である。このwork load は作業の規模や 速度を意味するので、作業によって固有の檤を持つこと になり、作業者の側ではその能力（体格・体力・欮娻度 など）によって心身の反応が異なるが、これは生体負担 とよび、生理的な機能に投映されるものを生理的負担と 爯んで区別する。 
自怔化システムでのwork loadの問題は、正常運転時 における適正な人員配置や異常・祭急事孯における必要 人員との落差の問題などと関連して、自峌化システム分 科会にとってはきわめて重要な課題である。

第 1 回の例会では

[パイロットのwork load の考え方・とらえ方] 長沢有恒 (航空医学実跨)

[レーダによる航空管制］

宮村宗明（運䑪省航空局管制本部）

C新型制御盤(PODIA) の設計 富沢羁昭 (東芝原子力電気計装技街部)

が、それそれwork loadに関通して発表された。

以下は、その既要である。

[パイロットのwork load の考え方・とらえ方]

パイロットのพork loadの测定・評傮の目的は

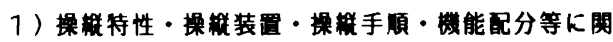
する人間工学的検討と設計

2 ) 我行運用または通航計画等に関する労科学的評 価と設計…であり、

分析・評価は

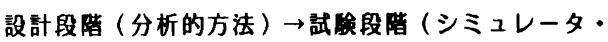
テストなど） $\rightarrow$ 飛行段陼（テスト・パイロットによる諸 测定など） $\rightarrow$ 運用段陼（追跡拥查など）…のステップで 行なわれ、これらは

技街・分析的（タスク分析，負荷情報分析など)

心理・行動的 (功作時間分析, 情報処理能力など)

生理・医学的 (生理学的. 生化学的など)

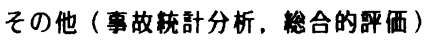

の方法で実施され飛行安全に奇与している。work load は作業だけでなく、生活の節までを対象とする必要が有 り、人間のすべてを包括して考慮することが重要である。 [レーダによる航空管制]

レーダ管制は[高速」の「3次元の移助物体」をコン トロールするが、この移動物体、すなわち航空機は「停 止不能!であり、管制業務は「制御対象の航空機を自身 の手では動かせない!、「事故の責任は問われても自身 は死めことがない」などに、その特徵がある。

レーダ管制のwork load の内容は

1)レーダ・スコープによる航空機の位罯の常時監視

2 ) 一定時間間隔の異常接近探查

3)航空譏の娌きの予测と計画

4 ) 対空通信

5 ) コンピュータ入力

6 ）思考・决断などと指示

7 ) その他

であるが、これを集的するとレーダから得た三次元情報 (航空幾の方位・距唯・高度)をもとに航空㙨の安全間 阿を設定することによるもので、最整的にはマン・マシ ン・インターフェイスの改善によって、レーダ面面上で
何機を管制できるのかの限度を求めるのが課題となる。 [新型制御盤（PODIA）の設計]

PODIA はPIant Operation by Displayed Information and Automation の略称で、制䇝盤にプロセス計算機能 の大幅活用と、カラーCRT を用いた情報表示・監視嘰能 を付加し

1)プラント運転の監視性・操作性向上

2 ) プラントの安全性の向上

3 ) プラント運転管理の充実

などを目的として開発されたものである。その奻果とし ては、人間と機械の情報交换のより婜密化、自助化によ る運転員の負担軽減、逜転性・安全性の向上である。同 題の起こりやすいプラントの起助・揨止時の通伝手順を 予めコンピュータに記憶させ、迠切なタイミングで通転 ガイドをCRT 上に表示する運転ガイドシステムはPODIA の大きい特徽のひとつである。

4. 自助化システムんおけるwork load の問影

安全人間工学部会の中のこの分科会が、自助化システ ムの安全問題に焦点を校って活栜することにした理由は、 各種のプラント、公共阅送閣などの規模が大型・高速 化が進み、ひとたび事故を起こせばその被害規模は飛踋 的に增大する可能性があり、こうした自助化システムの 安全に関わる人間工学的諸問顓こそ、この部会に棵せら れた使命であると判断したからである。

また、分科会活娌の最初のテーマとしてwork loadの 問題を取りあげたのは、自助化システムでのwork load の実卧が明らかでないことが多く、とくに正常时と異常 時とで従事員に要求される作業の复と舅の落差がきわめ て大きいといわれることを重視したためである。

（旧）安全人間工学部会では作業者の意绕レベルをつ エイスI〜IVに分類し、これのII〜正で作羍の行なえる ことが安全上で好ましいとした。また、事故の分析に当 たっても意謨レベルの応用の可能性を提案した。

しかし、現実的な問題としては、作業の実娒から作業 要求と作業遂行能力とのギャップを把握して、これを埋 める必要がある。過大なwork loadの場合はこれの睡娍 を、異常なほど過少なWork load による単調事毇にも相 広の対策が必要であろう。

これまでは、work load が通労などと開連して煡康席 害の面で重視されてきたが、すでに疲労徽候や単理事舞 での「注意低下」現象は明らかであり、単位時間当たり の作業能力にも限界のあることから、従事員にとって許 容できるwork load の管囲を模索し、これを機器設㖕と 作業設計の両面に提言できる筫料としてまとめる必要が ある。

5. 自動化システム分科会の当面の課顥

上記のような理由から、当面はwork load の夙題を棈 力的に検刢し、これを基硅に次ぎの鯟面に進むようにし たい。 